\title{
The Other Side of Child Neglect Charges: What Happens When There Are No Standard Criteria for Charging a Non-Offending Mother with Neglect?
}

\author{
Amy Neustein \\ Michael Lesher
}

Coohey's (2006) valuable research demonstrates that Child Protective Service (CPS) investigators use generally consistent criteria in determining when to charge a non-offending mother for failing to protect a child from sexual abuse. She concludes that the most reliable predictor that a formal charge of child neglect will be filed against a mother is her failure to consistently protect the child. Where a mother's protective behavior is less than consistent, the extent of her cooperation with CPS personnel can weigh in as an important factor. Other criteria include the firmness of her belief that abuse is occurring, which is closely linked to the clarity of the mother's information regarding the abuse. Evidence of mental health problems, such as drug or alcohol abuse or treatment for a psychological disorder, or indications of battering at the hands of the child's abuser, are also factors.

Amy Neustein, PhD, and Michael Lesher, Esq., are the co-authors of From Madness to Mutiny: Why Mothers Are Running from the Family Courts-And What Can Be Done About It (Series on Gender, Crime and Law, Northeastern University Press/University Press of New England, 2005).

Excerpts from From Madness to Mutiny: Why Mothers Are Running from the Family Courts-And What Can Be Done About It are reprinted with permission.

Address correspondence to: Amy Neustein, PhD, 1055 River Road Suite 1013 Edgewater, NT 07020.

Journal of Child Sexual Abuse, Vol. 15(4) 2006

Available online at http://jcsa.haworthpress.com

(c) 2006 by The Haworth Press, Inc. All rights reserved. doi:10.1300/J070v15n04_08 
Despite her finding that these criteria are applied consistently in Iowa (where she conducted her research), Coohey (2006) warns that "states that do not have clear decision-making criteria will have investigators who are more likely to rely on their personal beliefs and biases more often than states that have clear definitions for, for example, protectiveness." All this throws into sharp relief the shoot-from-the-hip standards employed by CPS agencies when mothers are charged with child neglect, not for failure to protect, but for making reports of abuse deemed "unfounded" by caseworkers. In these cases, we have found that no reliable criteria at all govern CPS behavior.

Neustein and Goetting (1999) ${ }^{1}$ examined a Nebraska case in which the mother was charged with "emotional neglect" based on her purportedly making a "false" report of sexual abuse by the child's father. No investigation was done by CPS to determine whether the mother's supposedly "false" complaint was in fact deliberately false and made with malicious intent, whether the mother had an underlying mental health problem causing her to have distortions about the child's father, or whether her child had been "harmed" by her allegedly false report of abuse. Instead, CPS took action against the mother, asking a court to have the child abruptly removed from the mother's custody and placed in foster care. The child was transferred to the custody of his father after a three-month stay in foster care. Living with the father, the child began to act out sexually in school by assaulting other children.

Although an extensive literature concludes that deliberately false reports of child sexual abuse are rare, researchers Everson and Boat (1989) have found that a certain proportion of CPS workers are more skeptical of children's claims of sexual abuse than is warranted by the actual rates of false reporting. We reported in our book From Madness to Mutiny (2005) that the problem is greater than mere skepticism by CPS personnel. In case after case, we found that CPS agencies actively prosecute mothers who report their suspicion that their children are being sexually abused. What is more, in contrast to Coohey's (2006) findings, mothers throughout the country who report abuse are not protected from a neglect charge by demonstrating the consistency of their belief in the abuse, nor by their display of consistently protective behavior in trying to stop the abuse.

Here are two case histories of neglect which appear in From Madness to Mutiny, both of which illustrate the danger of CPS's use of personal beliefs and biases rather than a set of clearly defined parameters for charging a mother with neglect. They are typical of many similar cases. 


\section{THE “BRAINWASHING/COACHING” MOTHER}

In 1986, a California case began hopefully for a protective mother when local CPS officials filed a petition against the father of a threeyear-old girl, charging him with (among other things) "cutting" the "minor's perineum [between the vagina and the rectum] with a knife."2 A caseworker testified in support of the charge. The child also made consistent reports of abuse, and repeated them to a family court judge. ${ }^{3}$ In response to all this, the judge ordered that the father's visits be supervised by CPS and scheduled a hearing for a later date to determine whether visitation should continue to be supervised.

However, in August 1987, CPS filed a petition seeking the child's placement in foster care. ${ }^{4}$ Ignoring the already-existing record of abuse by the father, CPS claimed that removal was necessary because of "the custody dispute." Weirdly, CPS complained that the child-who had reported being abused by her father on several occasions-was "forced to play roles ... in an attempt to please or appease her mother." The agency also complained that "the minor's mother behaves 'almost as if she is obsessed' with the belief that her daughter has been molested," and accused her of "coaching" the child to make reports of abuse..$^{5}$ Without further questions, the judge ordered the child be placed in foster care for several months. CPS refused to investigate at least eight reports of alleged child abuse by the father made by doctors and the child's therapist. ${ }^{6}$

In February 1988, the child complained again of molestation by her father. Once again, the mother reported the disclosure to CPS, whose officials called her "irrational." Despite strong medical evidence of abuse obtained in another state, CPS still did not alter its position.

\section{THE MOTHER WHO COMMUNICATED “FALSE INFORMATION” TO THE DOCTOR}

In 1991, a New York divorcing mother of two young girls, a registered nurse, was awarded sole custody of her two daughters, aged 7 and 3. Several months later, after a weekend visit of both girls with their father, the mother made a report to CPS, claiming a suspicion of sexual abuse. CPS took no action; the father then persuaded the family court to move the children to his custody, claiming the mother was unstable.

About a year later, while the mother was litigating for the return of her daughters, the younger child complained to her of pelvic pain. She also had a high fever. The mother took her to a hospital, where doc- 
tors were baffled by the symptoms. The mother suggested the child might be suffering from "pelvic inflammatory disease" (PID), and explained that such inflammation could have resulted from sexual abuse. The mother went on to complain to the doctors that CPS had not told the family court all it knew about the medical evidence of her daughter's alleged abuse.

Thanks to the information given by the mother, the doctors made a report to CPS that child sexual abuse had been alleged.

A few days later, the mother was stunned by the arrival of a formal petition accusing her of neglecting her daughter. She was particularly mystified by the specifics of the accusation, which were based entirely on her attempt to aid in her daughter's diagnosis and her criticism of the agency. Evidently CPS believed that this amounted to a form of child neglect:

Upon information and belief, on or about February 1, 1993 the Respondent [mother] caused false information to be given to representatives at Nyack Hospital resulting in the filing of a report of alleged child abuse or maltreatment [against the father] which alleged, inter alia, that the child has been sexually abused "regularly" by [the father]. Specifically, the report contained the false statement provided by the Respondent or her representative, that "child has a history of pelvic inflammatory disease"; and that the local Child Protective Services "withheld information from Family Court, given to her from [a child abuse expert], in which there was medical evidence that the child was sexually abused. ..."7

CPS also cited the mother's efforts to publicize her children's plight as further evidence of "child neglect":

Upon information and belief, in or around January and February 1993, the Respondent distributed a "flyer" in and around [the child's school], and Nyack Hospital while [the child] was a patient ... alleging, inter alia, that her daughter without specificity has been sexually abused by [the father] (p. 3).

A few months later, when the mother picked up her daughters for a visit, the elder one complained of pain in her vagina so severe she wanted to be taken to a hospital. The mother did so. This time, the medical evidence of abuse prompted officials to report that there had been "sexual offenses" against the girl, including "aggravated sexual abuse in the first degree ... in the second degree ... and/or rape in the second degree." Even then, CPS's attack on the mother did not abate. 


\section{CONCLUSION}

The absence of any logical criteria behind the charges of neglect we have examined underscores the need for vigorous reform. In the wake of the publication of From Madness to Mutiny, we have been asked by journalists and politicians what can be done to stem improper CPS action against mothers who report child sexual abuse. We believe the problem is severe enough to warrant legal action in each state by the state attorney general against local CPS agencies, seeking court orders requiring the agencies to apply reasonable and consistent criteria in charging mothers with neglect for reporting their suspicions of abuse. It is not clear that anything less drastic will bring consistency to such cases, without which no CPS agency can provide proper intervention in cases of child sexual abuse.

\section{NOTES}

1. This study, which was reported in The Journal of Child Sexual Abuse, examined 300 cases from around the country.

2. Published proceedings of Congressional Hearing Before the Subcommittee on Select Education, op. cit., April 20, 1992, p. 35.

3. Testimony of child, December 9, 1986. The child testified that her father "stuck his finger in my gina [sic] and my bottom and he cut me with a knife."

4. Neglect Petition, August 25, 1987, p. 2.

5. Id.

6. Id., pp. 22-23.

7. February 11, 1993, p. 3.

8. Police report, June 27, 1993.

\section{REFERENCES}

Everson, M. D., and Boat, B. W. (1989). False allegations of sexual abuse by children and adolescents. Journal of the American Academy of Child and Adolescent Psychiatry 28(2), 230-235.

Neustein, A., and Goetting, A. (1999). Judicial responses to the protective parent's complaint of child sexual abuse. Journal of Child Sexual Abuse 8(4), 103-122.

Neustein, A., and Lesher, M. (2005). From madness to mutiny: Why mothers are running from the family courts-And what can be done about It. Hanover, NH: University Press of New England.

doi:10.1300/J070v15n04_08 